(c) American Dairy Science Association, 2003.

\title{
Effect of Feeding Supplemental Fibrolytic Enzymes or Soluble Sugars with Malic Acid on Milk Production
}

\author{
J. L. Vicini,, ${ }^{*}$ H. G. Bateman, ${ }^{1}{ }^{1}$ M. K. Bhat,\# J. H. Clark†, \\ R. A. Erdman,§ R. H. Phipps,‡ M. E. Van Amburgh,\| \\ G. F. Hartnell, ${ }^{*}$ R. L. Hintz, ${ }^{*}$ and D. L. Hard ${ }^{\star}{ }^{2}$ \\ *Animal Agriculture Business \\ Monsanto Co. \\ St. Louis, MO 63198 \\ †Department of Animal Sciences \\ University of Illinois \\ Urbana, IL 61801 \\ $\ddagger$ Centre for Dairy Research \\ The University of Reading \\ Reading, UK RG2 9HX \\ $\S$ Department of Animal and Avian Sciences \\ University of Maryland \\ College Park, MD 20742 \\ |Department of Animal Science \\ Cornell University \\ Ithaca, NY 14853 \\ \#Institute of Food Research \\ Food Materials Science Division \\ Norwich Research Park \\ Colney, Norwich, NR4 7UA, UK
}

\begin{abstract}
Two trials were conducted to evaluate effects of feeding supplemental fibrolytic enzymes or soluble sugars and malic acid on milk production. In trial 1, 257 cows at four sites were fed a basal diet consisting of no more than $60 \%$ of forage DM as corn silage and less than $40 \%$ as alfalfa hay. Cows were assigned randomly within site, parity, and two stages of lactation to: 1) control; 2) enzyme A; 3) enzyme B; and 4) soluble sugars and malic acid. There was a $14-d$ pretreatment and an 84-d treatment period. Enzyme solutions were sprayed on either the forage component or the TMR each day while mixing feed. Trial 2 was similar, except 122 cows at one site in the United Kingdom were fed diets containing forage that was $75 \%$ corn silage and $25 \%$ grass silage, and all cows began the study between 25 to 31 DIM. Mean milk productions for 233 cows that completed trial 1 were $32.9,32.5,32.4$, and $32.9 \mathrm{~kg} / \mathrm{d}$ for control, enzyme A, enzyme B, and soluble sugars and malic acid, respectively. Mean milk productions for 116 cows that completed trial 2 were $28.2,27.9,28.8$, and
\end{abstract}

\footnotetext{
Received March 6, 2002.

Accepted May 24, 2002.

Corresponding author: J. L. Vicini; e-mail: john.l.vicini@ monsanto.com.

${ }^{1}$ Current address: Louisiana State University Agricultural Center, Baton Rouge, LA 70803

${ }^{2}$ Current address: Renessen LLC, Bannockburn, IL 60015.
}

$28.4 \mathrm{~kg} / \mathrm{d}$, respectively. In vitro analyses of the activities of enzyme solutions indicated that all major cellulose and hemicellulose degrading activities were present; however, the $\mathrm{pH}$ optima (approximate $\mathrm{pH}=4$ to 5) were more acidic, and the temperature optimum (approximately $50^{\circ} \mathrm{C}$ ) was greater than normal $\mathrm{pH}$ and temperature in the rumen. If fibrolytic activity in the rumen is a major mechanism of action of supplemental fibrolytic enzymes, it appears that considerable activity of these preparations was lost due to conditions in the rumen. In conclusion, feeding supplemental fibrolytic enzymes or malic acid with soluble sugars had no effect on milk production under the conditions used in this study.

(Key words: fibrolytic enzyme, malic acid, feed additive, milk production)

Abbreviation key: $\mathbf{C M}=$ carboxymethyl; $\mathbf{C N Y}=$ Cornell, NY; CPM = Cornell-Penn-Miner; DMSO = dimethyl sulphoxide; DNS = dinitrosalicylic acid; IL = Illinois; $\mathbf{M D}=$ Maryland; $\mathbf{M P}=$ metabolizable protein; SSMA = soluble sugars/malic acid; SNY $=$ Spruce Haven, NY.

\section{INTRODUCTION}

Feed costs represent the highest expense to dairy producers and, as a consequence, maximizing utilization of nutrients is essential to the profitability and sustainability of dairy farms. The largest fraction of feed energy that is not available to the animal is the 
undigested fibrous fraction. Methods that reduce this fraction could provide considerable benefit to dairy producers. Ruminal microorganisms, including bacteria and fungi, secrete specific enzymes to digest the fibrous fraction of feedstuffs. The host animal derives energy from the microbial cells and from various end products of fermentation. One potential method of improving utilization of fibrous feedstuffs is to increase their digestibility by increasing the quantity of fibrolytic enzymes that are available in the rumen.

Several approaches have been attempted for incorporating enzymes into diets for dairy cattle. Experiments have been conducted to study effects of adding fibrolytic enzymes to dry forages (Yang et al., 1999) or concentrates (Yang et al., 2000) before feeding and adding amylolytic and proteolytic enzymes targeted towards the starch-protein matrix of sorghum (Chen et al., 1995). In other studies, the effects of direct-fed fibrolytic enzymes applied either to the forage component of the diet (Schingoethe et al., 1999; Kung et al., 2000) or to a TMR (Beachemin et al., 1999) have been examined. Phipps et al. (2002) reviewed recent literature on the effect of direct-fed enzymes on feed intake and milk production. They noted that with few exceptions (Lewis et al., 1999), the direct-fed enzymes produced no significant effect on feed intake. While significant increases in milk production following treatment with direct-fed enzymes have been reported by Lewis et al. (1999), Schingoethe et al. (1999), and Zheng et al. (2000), other workers, including Beauchemin et al. (1999), Rode et al. (1999), and Kung et al. (2000), reported only numerical, nonsignificant increases. Also, Yang et al. (1999, 2000) reported significant changes in milk yield when enzymes were mixed at the time of manufacturing with alfalfa hay cubes or the concentrate portion, respectively. In the studies reviewed, the range in milk production response varied from 0 to 6.3 $\mathrm{kg} / \mathrm{d}$. Changes in milk composition due to the application of direct-fed enzymes were variable.

The objective of this study was to examine the effects of feeding one of two enzyme treatments on animal performance. In addition, a treatment group was also included to supply nutrients designed to support microbial growth. The nutrients included nonstructural carbohydrates, which were intended to supply energy to microbes and increase ruminal ammonia utilization and dicarboxylic acids to increase lactate utilization by Selenomonas ruminantium (Martin et al., 2000).

\section{MATERIALS AND METHODS}

\section{Trial \#1}

This trial was conducted at four sites. All sites followed the same experimental design, and the data from all four sites were pooled. Sites were: Central Maryland Research and Education Center, Ellicott City (MD); Spruce Haven Research Farm, Auburn, New York (SNY); University of Illinois research farm, Urbana (IL); and Cornell University Teaching and Research Center, Dryden, New York (CNY).

A total of 257 primiparous and multiparous Holstein cows were assigned to the study. All cows were between 8 and $166 \mathrm{DIM}$ at the start of the pretreatment period and were in good overall health, including good foot, leg, and udder conformation. The numbers of animals assigned within each site and parity group are presented in Table 1. Cows were assigned to the study at the beginning of a 14-d pretreatment period within site, parity, and stage of lactation. Stages of lactation were early or mid-lactation. Early-lactation cows were $<81$ DIM at the initiation of the treatment period at all sites except IL where they were $<73$ DIM.

Following the 14-d pretreatment period, cows were assigned randomly within blocks to one of four treatment groups. Treatments were: 1) control; 2) fibrolytic enzyme solution A (Finnfeeds, Helsinki, Finland); 3) fibrolytic enzyme solution B (Biovance Technologies, Inc., Omaha, NE); and 4) additive-containing soluble sugars and malic acid (SSMA; Milk Specialties, Dundee, IL). Both enzyme solutions contained activities derived from Trichoderma longibrachiatum. Enzyme solution A was added at $1.25 \mathrm{~L} / 1000 \mathrm{~kg}$ of forage DM and was diluted with water and sprayed on forage in the TMR wagon at $10 \mathrm{~L} / 1000 \mathrm{~kg}$ of forage (as fed). Enzyme solution B was added at $2 \mathrm{~L} / 1000 \mathrm{~kg}$ of total ration DM and was diluted and sprayed on the mixed ration at 10 L/1000 kg (as fed). Enzymes were sprayed on feed each morning during the mixing process. Treatment \#4 was added daily to the diet as a dry supplement to provide approximately $0.227 \mathrm{~kg} / \mathrm{cow}$ per day. Levels of enzyme addition used and the type of feed (forage only or TMR) to apply the enzyme mixture were based on recommendations from the enzyme manufacturers. The treatment phase lasted for $84 \mathrm{~d}$. Feeds were mixed at each site for a specified time in a mixer wagon. Times used across sites ranged from 5 to $10 \mathrm{~min}$, and the time used at each site resulted in a homogeneous mixture and additives were well dispersed.

Cows were fed a TMR (Table 2) formulated to meet or exceed NRC (1989) requirements. At each site, the feed for $1 \mathrm{~d}$ was mixed once daily, and cows were fed once daily (except Illinois where the daily ration was weighed out every morning but fed in a.m. and p.m. offerings). Also, diets were evaluated using the CornellPenn-Miner (CPM) model (Barry et al., 1994) to assure that metabolizable protein (MP) allowable milk was at least $2 \mathrm{~kg} / \mathrm{d}$ greater than ME allowable milk. Across sites, forages were restricted to no more than $60 \%$ of 
Table 1. Numbers of cows starting the trials at each site and numbers of cows within parity and start DIM blocks.

\begin{tabular}{|c|c|c|c|c|c|}
\hline \multirow[b]{2}{*}{ Site } & \multicolumn{2}{|c|}{ \#Primiparous } & \multicolumn{2}{|c|}{ \#Multiparous } & \multirow[b]{2}{*}{ Tota } \\
\hline & Early block & Late block & Early block & Late block & \\
\hline \multicolumn{6}{|l|}{ Trial 1} \\
\hline MD & 14 & 5 & 14 & 27 & 60 \\
\hline SNY & 15 & 22 & 6 & 34 & 77 \\
\hline IL & 8 & 8 & 16 & 28 & 60 \\
\hline CNY & 17 & 13 & 18 & 12 & 60 \\
\hline Total & 54 & 48 & 54 & 101 & 257 \\
\hline \multicolumn{6}{|l|}{ Trial 2} \\
\hline UK & 37 & & 85 & & 122 \\
\hline
\end{tabular}

forage DM as corn silage and no less than $40 \%$ of forage as alfalfa hay. Cows were fed ad libitum.

Cows were milked twice (CNY, MD, IL) or three (SNY) times daily. Samples of each milking were collected $1 \mathrm{~d} / \mathrm{wk}$, and they were analyzed using an automated infrared analyzer for fat and protein (AOAC, 1990; Dairy One, Ithaca, NY). Amounts of feed offered and refused were weighed daily for each cow. At IL, weighback for each cow was scored every morning for moisture content of the refused feed. Scores were from 1 (driest) to 4 (wettest). Individual cow refusal samples were measured for DM at 2- to 4 -wk intervals. Using these samples, an average DM was calculated for scores 1 through 4 . The average for a specific score was then used to estimate the DM content of all refusal amounts with that wetness score.

Feed ingredients and control TMR were sampled weekly. An aliquot of each sample was frozen, and for-

Table 2. Ingredient and nutrient composition of basal diet at each site.

\begin{tabular}{|c|c|c|c|c|c|}
\hline & MD & $\mathrm{SNY}$ & IL & $\mathrm{CNY}$ & UK \\
\hline \multicolumn{6}{|l|}{ Ingredient (\%) DM } \\
\hline Corn silage & 29.1 & 29.2 & 27.0 & 25.7 & 42.7 \\
\hline Alfalfa hay & 19.4 & 19.5 & 25.0 & 16.7 & \\
\hline Grass silage & & & & & 14.3 \\
\hline Cottonseed & 10.2 & 7.1 & 10.0 & 9.9 & \\
\hline Corn, ground shelled & 26.1 & & 22.9 & & \\
\hline Corn, high moisture & & 19.7 & & 29.4 & \\
\hline Wheat & & & & & 20.1 \\
\hline Soybean meal, $48 \%$ CP & 5.4 & 9.5 & 11.0 & 5.2 & \\
\hline Bypass SBM $^{1}$ & 7.7 & 3.9 & & 8.0 & 5.9 \\
\hline Canola meal & & & & & 10.1 \\
\hline Fishmeal & & 0.6 & 1.0 & & 1.4 \\
\hline Distillers grain & & 3.2 & & & \\
\hline Bakery waste & & 3.8 & & & \\
\hline Urea & & 0.3 & & & \\
\hline Protein supplement $^{2}$ & & & & 2.1 & \\
\hline Molasses & & & & & 4.0 \\
\hline $\mathrm{Fat}^{3}$ & & & & & 0.6 \\
\hline Minerals & 2.2 & 3.3 & 3.4 & 2.0 & 0.9 \\
\hline \multicolumn{6}{|l|}{ Nutrient analysis, \% DM } \\
\hline $\mathrm{DM}^{4}$ & 49.15 & 53.80 & 67.90 & 53.04 & 44.60 \\
\hline $\mathrm{CP}$ & 16.00 & 17.77 & 17.24 & 18.49 & 19.10 \\
\hline $\mathrm{NE}_{\mathrm{L}}^{5}$ & 1.59 & 1.61 & 1.57 & 1.68 & 1.61 \\
\hline $\mathrm{ADF}$ & 23.38 & 27.40 & 25.42 & 19.74 & 22.32 \\
\hline $\mathrm{NDF}$ & 39.98 & 37.60 & 38.06 & 30.14 & 37.60 \\
\hline $\mathrm{NFC}^{6}$ & 32.73 & 33.27 & 33.40 & 40.30 & 33.32 \\
\hline Ether extract & 5.95 & 5.53 & 4.96 & 4.81 & 3.62 \\
\hline
\end{tabular}

${ }^{1}$ Soyplus (West Central Soy, Ralston, IA).

${ }^{2} \mathrm{Hi}$-Lys (Agway Inc., Syracuse, NY).

${ }^{3}$ Megalac (Volac International, Royston, UK).

${ }^{4}$ Percentage of wet weight.

${ }^{5} \mathrm{Mcal} / \mathrm{kg}$.

${ }^{6}$ Nonfiber carbohydrate $[100-(\mathrm{NDF}, \%+\mathrm{CP}, \%+$ ether extract, $\%+$ ash, $\%)]$. 
age samples were tested weekly for DM to adjust the as-fed amounts of forage and concentrate in the TMR on a weekly basis. At the completion of the trial, samples were composited for the pretreatment period and for every 4-wk interval during the treatment period. Composite samples were analyzed by wet chemistry methods (Dairy One, Ithaca, NY).

Body weights were measured at the beginning of the treatment period and every 4 wk thereafter. Cows were observed daily and health findings were recorded.

\section{Trial \#2}

A second trial using the same four treatment groups was conducted at the University of Reading using 122 British Holstein-Friesian cows (Table 1). The experimental design for trial 2 was similar to trial 1, except there was no blocking by stage of lactation. Instead, all cows began the pretreatment between 11 and 17 DIM, and treatments were initiated $14 \mathrm{~d}$ later between 25 and 31 DIM. Also, the diet contained approximately $75 \%$ of the forage DM as corn silage and $25 \%$ as grass silage (Table 2).

\section{Enzyme Assays}

Enzyme preparations A and B were assayed for xylanase, endoglucanase, exoglucanase, $\beta$-glucosidase, $\beta$ xylosidase, $\alpha$-L-arabinofuranosidase, $\alpha$-L-arabinopyranosidase, acetyl esterase, and $\alpha$-glucuronidase as described below.

Xylanase activity. Xylanase was assayed as described by Bailey et al. (1992). A 15-ml test tube containing $1.8 \mathrm{ml}$ of $1.0 \%$ (wt/vol) birchwood xylan (Roth 7500) prepared in $50 \mathrm{mM}$ sodium citrate buffer $\mathrm{pH} 5.3$, and $0.196 \mathrm{ml}$ of distilled water were preincubated at $50^{\circ} \mathrm{C}$ for $10 \mathrm{~min}$. The enzyme reaction was initiated by adding $4 \mu \mathrm{l}$ of 1:200 diluted enzyme sample, and the reaction continued for $5 \mathrm{~min}$ at $50^{\circ} \mathrm{C}$. The reaction was terminated by adding $3 \mathrm{ml}$ of dinitrosalicylic acid (DNS) reagent, and the reducing sugars released were determined by the DNS method (Miller, 1959). The unit of enzyme activity was expressed as the amount of enzyme required to release $1 \mu \mathrm{mol}$ of reducing sugars as xylose equivalent $\min ^{-1} \cdot \mathrm{g}^{-1}$ of the enzyme sample.

Endoglucanase activity. Endoglucanase was assayed as described by Wood and Bhat (1988). A 15-ml test tube containing $1 \mathrm{ml}$ of $1.0 \%$ (wt/vol) of carboxymethyl cellulose (CM-cellulose, medium viscosity), 0.5 $\mathrm{ml}$ of $100 \mathrm{mM}$ sodium acetate buffer $\mathrm{pH} 5.0$, and 0.492 $\mathrm{ml}$ of distilled water was preincubated at $50^{\circ} \mathrm{C}$ for 10 $\mathrm{min}$. At the end of $10 \mathrm{~min}, 8 \mu \mathrm{l}$ of 1:200 diluted enzyme sample was added and incubated for a further $15 \mathrm{~min}$ at $50^{\circ} \mathrm{C}$. The reaction was terminated by adding $3 \mathrm{ml}$ of DNS reagent, and the amount of reducing sugars released was determined as described above. The unit of enzyme activity was expressed as the amount of enzyme required to release $1 \mu \mathrm{mol}$ of reducing sugars as glucose equivalent $\min ^{-1} \cdot \mathrm{g}^{-1}$ of the enzyme sample.

Exoglucanase activity. Exoglucanase was assayed as described by Wood and Bhat (1988). A 15-ml test tube containing $1 \mathrm{ml}$ of $1.0 \%$ (wt/vol) of Avicel (Fluka, Sigma-Aldrich, Dorset, UK), $0.5 \mathrm{ml}$ of $100 \mathrm{~m} M$ sodium acetate buffer $\mathrm{pH} 5.0$, and $0.492 \mathrm{ml}$ of distilled water was preincubated at $50^{\circ} \mathrm{C}$ for $10 \mathrm{~min}$. At the end of 10 min, $8 \mu \mathrm{l}$ of 1:250 diluted enzyme sample was added, and the tubes were incubated for a further $2 \mathrm{~h}$ at $50^{\circ} \mathrm{C}$. The reaction was terminated by placing the tubes in a boiling water bath for $10 \mathrm{~min}$. The tubes were centrifuged at $1350 \times g$ for $10 \mathrm{~min}$, and the reducing sugars present in the supernatant were determined by the DNS method (Miller, 1959). The unit of enzyme activity was expressed as the amount of enzyme required to release $1 \mu \mathrm{mol}$ of reducing sugars as glucose equivalent $\min ^{-1} \cdot \mathrm{g}^{-1}$ of the enzyme sample.

$\beta$-Glucosidase, $\beta$-xylosidase, $\alpha$-L-arabinofuranosidase, $\alpha$-L-arabinopyranosidase, and $\alpha-D$-glucuronidase activities. $\beta$-Glucosidase, $\beta$-xylosidase, $\alpha$ L-arabinofuranosidase, $\alpha$-L-arabinopyranosidase, and $\alpha$-D-glucuronidase were assayed using microtiter plates in duplicate and using two different enzyme concentrations. A $150-\mu \mathrm{l}$ reaction volume containing 100 $\mu \mathrm{l}$ of $3 \mathrm{~m} M$ substrate, $37.5 \mu \mathrm{l}$ of $100 \mathrm{~m} M$ sodium acetate buffer, $\mathrm{pH}$ 5.0, and $12.5 \mu \mathrm{l}$ of enzyme (1:20 to 1:100 diluted) was incubated at $40^{\circ} \mathrm{C}$ for $15 \mathrm{~min}$. The substrate for each activity was the respective $p$-nitrophenyl-glycoside (i.e., $p$-nitrophenyl- $\beta$-D-glucoside for $\beta$ glucosidase). The reaction was terminated by adding $150 \mu \mathrm{l}$ of $0.4 M$ glycine buffer, $\mathrm{pH} 10.8$. The absorbance was read using an Anthos Microplate reader at $405 \mathrm{~nm}$. The unit of enzyme activity was expressed as $\mu \mathrm{mol}$ of $p$-nitrophenol released $\mathrm{min}^{-1} \cdot \mathrm{g}^{-1}$ of enzyme sample.

Acetyl esterase activity. Acetyl esterase was measured using $p$-nitrophenyl acetate by microtiter plate method. $p$-Nitrophenyl acetate $(10 \mathrm{~m} M)$ was dissolved in $20 \%$ ( $\mathrm{vol} / \mathrm{vol}$ ) of dimethyl sulphoxide (DMSO), since it was partially soluble in water. However, the above concentration of DMSO had little effect on enzyme activity. Also, the $p$-nitrophenyl acetate was unstable at temperatures $>50^{\circ} \mathrm{C}$ and $\mathrm{pH}$ 7.0. Therefore, the initial rate of the reaction was measured using potassium phosphate buffer at $\mathrm{pH} 6.8$ and at $37^{\circ} \mathrm{C}$ for $10 \mathrm{~min}$ at $405 \mathrm{~nm}$. The reaction was linear up to $10 \mathrm{~min}$ and the enzyme activity was determined based on the absorbance at the end of $5 \mathrm{~min}$ of incubation. Thus, a typical $200-\mu \mathrm{l}$ reaction mixture contained $100 \mu \mathrm{l}$ of 10 $\mathrm{m} M p$-nitrophenyl acetate in $20 \% \mathrm{DMSO}, 50 \mu \mathrm{l}$ of 50 $\mathrm{m} M$ potassium phosphate buffer, $\mathrm{pH} 6.8$ and $50 \mu \mathrm{l}$ of 
VICINI ET AL.

Table 3. Numbers of cows that started trial, removed from study, and in final analyses for each trial.

\begin{tabular}{|c|c|c|c|c|c|}
\hline & Control & Enzyme A & Enzyme B & SSMA & Total \\
\hline \multicolumn{6}{|l|}{ Trial 1} \\
\hline Started trial & 62 & 66 & 63 & 66 & 257 \\
\hline Removed during study & 3 & 3 & 2 & 3 & 11 \\
\hline Did not follow protocol ${ }^{1}$ & 1 & 3 & 1 & 0 & 5 \\
\hline Health drop ${ }^{2}$ & 2 & 2 & 2 & 2 & 8 \\
\hline Total in analysis & 56 & 58 & 58 & 61 & 233 \\
\hline \multicolumn{6}{|l|}{ Trial 2} \\
\hline Started trial & 28 & 32 & 30 & 32 & 122 \\
\hline Removed during study & 2 & 1 & 1 & 2 & 6 \\
\hline Did not follow protocol & 0 & 0 & 0 & 0 & 0 \\
\hline Health drop & 0 & 0 & 0 & 0 & 0 \\
\hline Total in analysis & 26 & 31 & 29 & 30 & 116 \\
\hline
\end{tabular}

1:50 diluted enzyme. The unit of enzyme activity was expressed as $\mu \mathrm{mol}$ of $p$-nitrophenol released $\mathrm{min}^{-1} \cdot \mathrm{g}^{-1}$ of enzyme sample.

Determination of $\mathrm{pH}$ optimum of cellulase and hemicellulase activities. For the determination of $\mathrm{pH}$ optimum of xylanase, endoglucanase, and exoglucanase, $1 \mathrm{ml}$ of $1 \%$ substrate (birchwood xylan, CM-cellulose, medium viscosity, or Avicel) prepared in distilled water was mixed with $0.9 \mathrm{ml}$ of buffer $(50 \mathrm{mM})$ having varying $\mathrm{pH}$ values (citrate-phosphate, $\mathrm{pH} 2.6$ to 7.0; potassium-phosphate, $\mathrm{pH} 6.6$ to 8.0 , and boric acidsodium hydroxide, 8.0 to 9.0 ) and incubated at $50^{\circ} \mathrm{C}$ for $10 \mathrm{~min}$. At the end of $10 \mathrm{~min}, 0.1 \mathrm{ml}$ of suitably diluted enzyme sample was added to the reaction mixture, and the assay was carried out as described above. The reducing sugars released were determined by the DNS method (Miller, 1959), and the $\mathrm{pH}$ optimum was determined by plotting the unit of enzyme activity versus $\mathrm{pH}$.

The $\mathrm{pH}$ optimum of $\beta$-glucosidase, $\beta$-xylosidase, $\alpha$-Larabinofuranosidase, and $\alpha$-L-arabinopyranosidase was determined by using microtiter plates as described above and using the above mentioned three buffer systems. In all cases, the $\mathrm{pH}$ optimum was determined by plotting the unit of enzyme activity versus $\mathrm{pH}$.

Determination of temperature optimum of xylanase, endoglucanase, and exoglucanase activities. The optimum temperatures were determined by measuring the xylanase, endoglucanase, and exoglucanase activities present in samples $\mathrm{A}$ and $\mathrm{B}$ at temperatures between 10 and $70^{\circ} \mathrm{C}$ at the optimum $\mathrm{pH}$ of each enzyme activity. The assay conditions for each activity were as described above. The optimum temperature of each enzyme activity was determined by plotting the activity versus temperature.

\section{Statistical Analyses}

Due to differences in the experimental design of the two production trials, each trial was analyzed sepa- rately. Data were analyzed by SAS (1997) using the following model:

$$
\begin{aligned}
\mathrm{Y}_{\mathrm{ijkl}}=\mathrm{U}+\mathrm{T}_{\mathrm{i}}+ & \mathrm{S}_{\mathrm{j}}+\mathrm{TS}_{\mathrm{ij}}+\mathrm{B}_{\mathrm{k}}+\mathrm{TB}_{\mathrm{ik}}+\mathrm{M}_{\mathrm{l}}+\mathrm{TM}_{\mathrm{il}} \\
& +\mathrm{bPRE}_{\mathrm{ijkl}}+\mathrm{e}_{\mathrm{ijkl}},
\end{aligned}
$$

where $\mathrm{U}=$ overall mean, $\mathrm{T}_{\mathrm{i}}=$ treatment effect, $\mathrm{S}_{\mathrm{j}}=$ site effect, $\mathrm{TS}_{\mathrm{ij}}=$ treatment by site interaction, $\mathrm{B}_{\mathrm{k}}=$ stage of lactation block, $\mathrm{TB}_{\mathrm{ik}}=$ treatment by stage of lactation interaction, $\mathrm{M}_{\mathrm{l}}=$ parity group, $\mathrm{TM}_{\mathrm{il}}=$ treatment by parity interaction, $\mathrm{PRE}_{\mathrm{ijkl}}=$ pretreatment covariate, $\mathrm{b}=$ regression coefficient for $\mathrm{PRE}_{\mathrm{ijkl}}$, and $\mathrm{e}_{\mathrm{ijkl}}=$ residual error. When $P<0.25$, the treatment by site interaction was used as the error term to test significance of the treatment main effect. Treatment effects were deemed significant at $P<0.05$. Data for trial 2 were analyzed separately using a similar model excluding the site and stage of lactation terms.

\section{RESULTS}

\section{Production Trials}

Health of cows was generally good throughout both trials 1 and 2. Eleven cows were removed from trial 1, and six cows were removed from trial 2 (Table 3 ). The most common reasons for removal were displaced abomasum, mastitis, foot problems, and not adapting to tiestalls. Additionally, data from animals that completed the study but were identified as having health problems that could impact production results were removed. Both the study investigator and the investigator for each site evaluated these cows individually, and if both investigators agreed, data for these animals were excluded from analysis. Data from eight animals in trial 1 were removed due to health problems such as early dry-off and foot health. Data from five additional animals were not included due to not meeting protocol defined DIM at the initiation of treatments. There were 
Table 4. Feed consumption, milk production and composition, and change in BW of cows fed basal diets or diets supplemented with enzymes or soluble nutrients at four US sites (trial 1).

\begin{tabular}{llllll}
\hline & Control & Enzyme A & Enzyme B & SSMA & SEM $^{1}$ \\
\hline No. cows & 56 & 58 & 58 & 61 & \\
DMI, kg/d & 21.2 & 21.8 & 21.4 & 21.4 & 0.24 \\
Milk, kg/d & 32.9 & 32.5 & 32.4 & 32.9 & 0.45 \\
$3.5 \%$ FCM, kg/d & 33.9 & 33.5 & 33.5 & 34.2 & 0.49 \\
Milk fat, \% & 3.73 & 3.70 & 3.71 & 3.74 & 0.041 \\
Milk CP, \% & 3.15 & 3.17 & 3.17 & 3.18 & 0.017 \\
Log $_{10}$ SCC & 4.8 & 4.8 & 4.9 & 4.9 & 0.04 \\
BW change $^{2}, \mathrm{~kg}$ & 28.0 & 37.2 & 28.7 & 31.9 & 4.92 \\
\hline
\end{tabular}

${ }^{1}$ There were no differences $(P>0.10)$ between treatments.

${ }^{2}$ Weight at end of treatment period minus weight at beginning of treatment period.

no indications that removals were affected by treatments.

Results from trials 1 and 2 are presented in Tables 4 and 5, respectively. For both trials, milk production was not affected $(P>0.10)$ by treatments. Milk fat and milk protein percentages also were not affected by feeding these additives. Additionally, there were no effects of treatment on SCC, feed intake, or BW change during the 84-d treatment period. In trial 1 , there were no treatment $\times$ site interactions, indicating that responses were not obtained within any one site. There were no treatment interactions with stage of lactation from trial 1 , indicating that responses were not dependent on stage of lactation. Additionally, for both trials 1 and 2, there were no treatment $\times$ parity interactions, suggesting that treatments were not effective for either parity group.

\section{In Vitro Enzyme Activities}

Enzyme preparations A and B contained all the major hemicellulase (xylanase, $\beta$-xylosidase, $\alpha$-L-arabinofuranosidase, $\alpha$-L-arabinopyranosidase, acetyl esterase, and $\alpha$-D-glucuronidase) and cellulase (endoglucanase, exoglucanase, and $\beta$-glucosidase) activities (Table 6). In general, the levels of all cellulase and hemicellulase activities in sample A were higher than in sample B, except for $\alpha$-L-arabinofuranosidase (Table 6). Also, both A and B enzyme samples had greater xylanase and endoglucanase activities compared with the other cellulase and hemicellulase activities (Table 6).

The $\mathrm{pH}$ activity profiles and the $\mathrm{pH}$ optimum of each activity in enzyme samples $A$ and $B$ when measured at $50^{\circ} \mathrm{C}$ are presented in Figure 1 and Table 6 . The xylanase from enzyme samples $\mathrm{A}$ and $\mathrm{B}$ was active between $\mathrm{pH} 3.0$ to 9.0 (Figure 1) and had broad $\mathrm{pH}$ optima between 5.0 to 6.0 and 5.5 to 5.8, respectively (Table 6). The highest activity of xylanase from both enzyme samples at optimal $\mathrm{pH}$ was similar (Figure 1).

The endoglucanase from enzyme samples A and B was active between $\mathrm{pH} 2.6$ to 8.0, but the endoglucanase from sample A had slightly broader $\mathrm{pH}$ optimum $(4.0$ to 5.5$)$ and higher activity than that from sample B (4.0 to 4.5; Figure 1). The exoglucanase from samples $\mathrm{A}$ and $\mathrm{B}$ was active between $\mathrm{pH} 2.6$ to 7.0 (Figure 1), but this enzyme had the optimal activity between $\mathrm{pH} 4.2$ to 4.6 and at $\mathrm{pH} 5.0$, respectively. The $\beta$-glucosidase from both enzyme samples was active between $\mathrm{pH} 2.6$ to 8.0, but optimally at $\mathrm{pH} 4.5$ (Table 6). Nevertheless, the $\beta$-glucosidase from sample A had a broader $\mathrm{pH}$ optimum and greater activity than that from sample B.

The $\beta$-xylosidase from samples $\mathrm{A}$ and $\mathrm{B}$ was active between $\mathrm{pH} 2.6$ to 8.0 (Figure 1), but optimally active between $\mathrm{pH} 2.6$ to 4.0 . The $\beta$-xylosidase activity in both enzyme samples decreased with the increase in $\mathrm{pH}$ from 4.0 to 8.0. Thus, the $\beta$-xylosidase from enzyme samples

Table 5. Feed consumption, milk production and composition, and change in BW of cows fed basal diets or diets supplemented with enzymes or soluble nutrients at one UK site (trial 2).

\begin{tabular}{|c|c|c|c|c|c|}
\hline & Control & Enzyme A & Enzyme B & SSMA & SEM $^{1}$ \\
\hline No. cows & 26 & 31 & 29 & 30 & \\
\hline DMI, kg/d & 18.5 & 18.3 & 18.3 & 18.2 & 0.24 \\
\hline Milk, kg/d & 28.2 & 27.9 & 28.8 & 28.4 & 0.46 \\
\hline $3.5 \%, \mathrm{FCM}, \mathrm{kg} / \mathrm{d}$ & 30.2 & 29.4 & 29.6 & 29.9 & 0.52 \\
\hline Milk fat, $\%$ & 3.95 & 3.83 & 3.69 & 3.88 & 0.097 \\
\hline Milk CP, \% & 3.34 & 3.35 & 3.36 & 3.34 & 0.029 \\
\hline $\log _{10}$ SCC & 4.5 & 4.5 & 4.6 & 4.5 & 0.06 \\
\hline $\mathrm{BW}$ change ${ }^{2}, \mathrm{~kg}$ & 23.9 & 25.1 & 27.8 & 34.1 & 6.72 \\
\hline
\end{tabular}

${ }^{1}$ There were no differences $(P>0.10)$ between treatments.

${ }^{2}$ Weight at end of treatment period minus weight at beginning of treatment period. 
VICINI ET AL.

Table 6. Enzyme activities and $\mathrm{pH}$ optima of Trichoderma longibrachiatum-derived enzyme preparations $\mathrm{A}$ and $\mathrm{B}$.

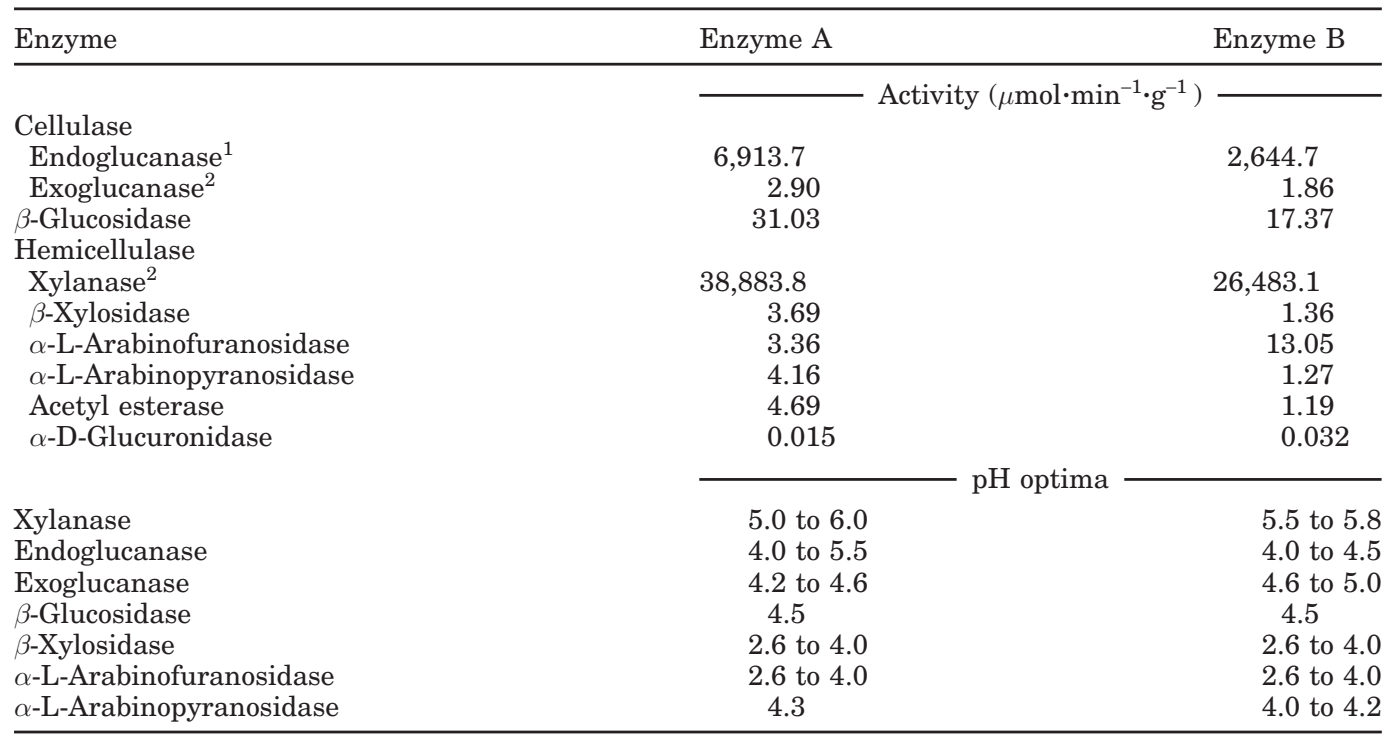

${ }^{1} \mathrm{DNS}$ method.

${ }^{2}$ Birchwood xylan at pH 5.3.

A and $\mathrm{B}$ showed an identical $\mathrm{pH}$ versus activity profile except the total activity in sample A was twofold higher than that from sample B.

Both $\alpha$-L-arabinofuranosidase and $\alpha$-L-arabinopyranosidase from enzyme samples $\mathrm{A}$ and $\mathrm{B}$ were active between $\mathrm{pH} 2.6$ to 7.0 (Figure 1). The $\alpha$-L-arabinofuranosidase from enzyme samples A and B was optimally active between $\mathrm{pH} 2.6$ to 4.0 , whereas the $\alpha$-L-arabinopyranosidase from enzyme samples $\mathrm{A}$ and $\mathrm{B}$ was optimally active at $\mathrm{pH} 4.3$ and at $\mathrm{pH}$ between 4.0 to 4.2 , respectively. At optimum $\mathrm{pH}$, the activity of $\alpha$-L-arabinofuranosidase from enzyme sample $\mathrm{B}$ was five times higher than that from enzyme sample $\mathrm{A}$, whereas the activity of $\alpha$-L-arabinopyranosidase from enzyme sample A was four times higher than that from enzyme sample B.

The xylanase from enzyme sample B was optimally active at $50^{\circ} \mathrm{C}$, whereas that from enzyme sample A was optimally active at $60^{\circ} \mathrm{C}$ (Figure 2). Xylanase from both enzyme samples showed only $10 \%$ of the optimal activity up to $20^{\circ} \mathrm{C}$ (Figure 2). Nevertheless, the activity of xylanase from both samples increased sharply with an increase in temperature up to 50 to $60^{\circ} \mathrm{C}$ and decreased sharply above $60^{\circ} \mathrm{C}$. The endoglucanase from both enzyme samples was optimally active at $60^{\circ} \mathrm{C}(\mathrm{Fig}$ ure 2). Above $60^{\circ} \mathrm{C}$, the endoglucanase activity from sample B decreased rapidly, whereas the endoglucanase activity of sample A decreased more slowly. However, up to $40^{\circ} \mathrm{C}$, the endoglucanase from both enzyme samples showed only $20 \%$ of the optimal activity. The exoglucanase from enzyme samples A and B was opti- mally active at $50^{\circ} \mathrm{C}$ (Figure 2). The $\mathrm{pH}$ and temperature activity profiles clearly suggested that the cellulase and hemicellulase activities from these enzyme samples would be less efficient in the rumen because $\mathrm{pH}$ and temperature would not be optimum.

\section{DISCUSSION}

The current trials consisted of a relatively large number of cows, were conducted at multiple sites, used both early and mid-lactation dairy cows, and were of a relatively long duration. Under these circumstances, there were no differences in milk production between control cows and any of the additive-fed cows. These results contrast with those of Lewis et al. (1999), Schingoethe et al. (1999) and Zheng et al. (2000), that reported significant differences, and Beauchemin et al. (1999), Rode et al. (1999), and Kung et al. (2000), that only reported numerical but nonsignificant increases in milk production due to addition of direct-fed enzymes.

Several mechanisms have been proposed whereby supplemental enzymes could improve animal performance (Beauchemin and Rode, 1996). The most obvious mechanism would be improved digestibility of cellulose or hemicellulose. Improved digestibility has been measured in several studies with dairy cattle (Beauchemin et al., 1999; 2000; Rode et al., 1999; Yang et al., 1999; 2000) and has been associated with increased rate of particle outflow from the rumen, possibly caused by increased rate of digestion and/or lower rumen fluid viscosity, but has not been associated with increased 

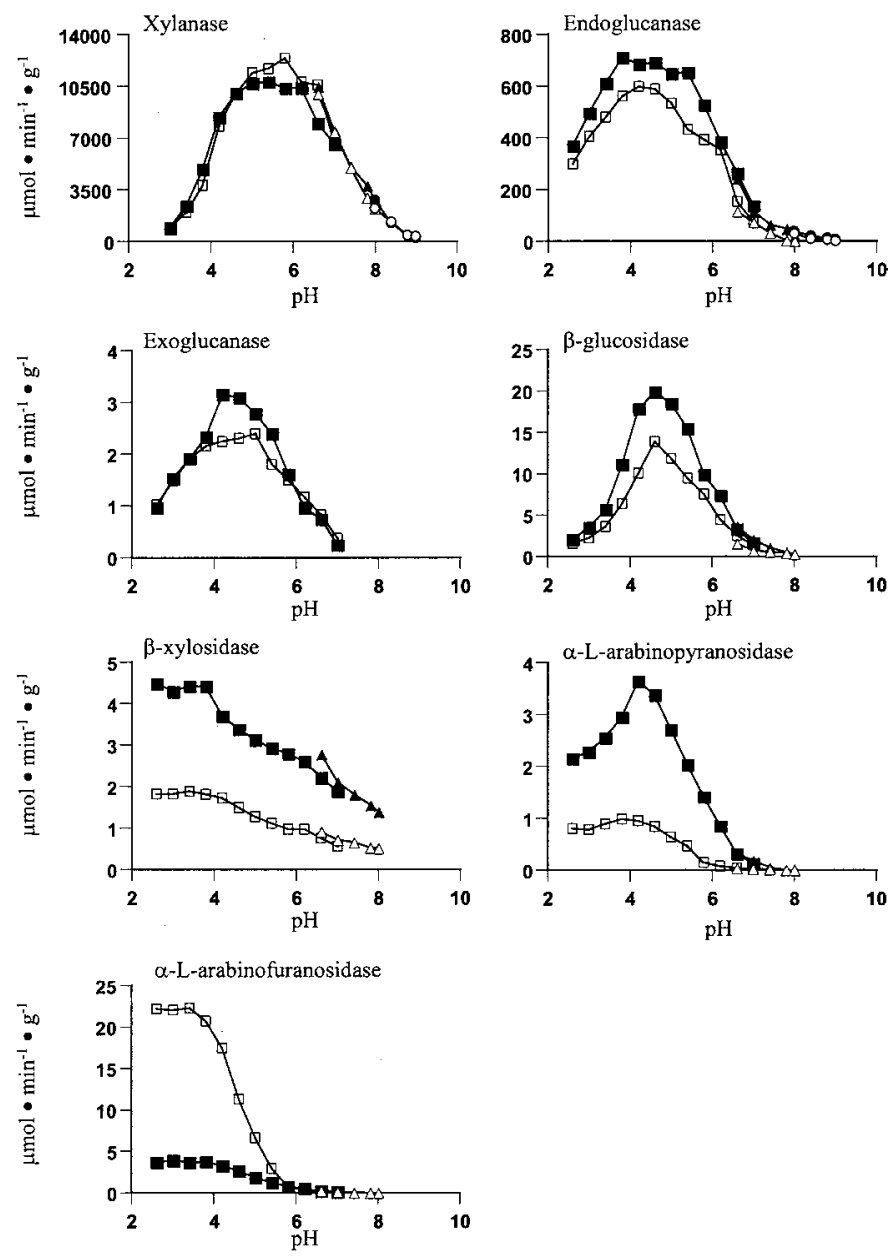

Figure 1. Effect of $\mathrm{pH}$ on cellulase and hemicellulase activities of enzyme samples A (closed symbols) and B (open symbols). Buffers used were: sodium acetate, $\mathrm{pH} 3.0$ to 7.0 (squares); potassium phosphate, $\mathrm{pH} 6.6$ to 8.0 (triangles); and boric acid/sodium hydroxide, $\mathrm{pH}$ 8.0 to 9.0 (circles).

DMI. Under these conditions, if retention time is reduced, the benefits of enhanced fibrolytic activity may be small.

The lack of production responses and the $\mathrm{pH}$ optima curves and optimum temperatures suggest that the amount of supplemental enzymatic activity for degradation of cellulose and hemicellulose may be limited in the environment of the rumen of the cows offered the diet used in the current study. Typical $\mathrm{pH}$ of the rumen is higher than the $\mathrm{pH}$ optima that were obtained, and ruminal temperature is lower than the optimal temperature for enzymatic activity. In general, at $\mathrm{pH}=6$ most of the enzymatic activities of either enzyme A or B will be reduced by about two-thirds of their optimal activity, and at $38^{\circ} \mathrm{C}$, these activities will be further reduced by two-thirds. Therefore, the combined effects of $\mathrm{pH}$ and temperature that exist in the rumen would suggest that
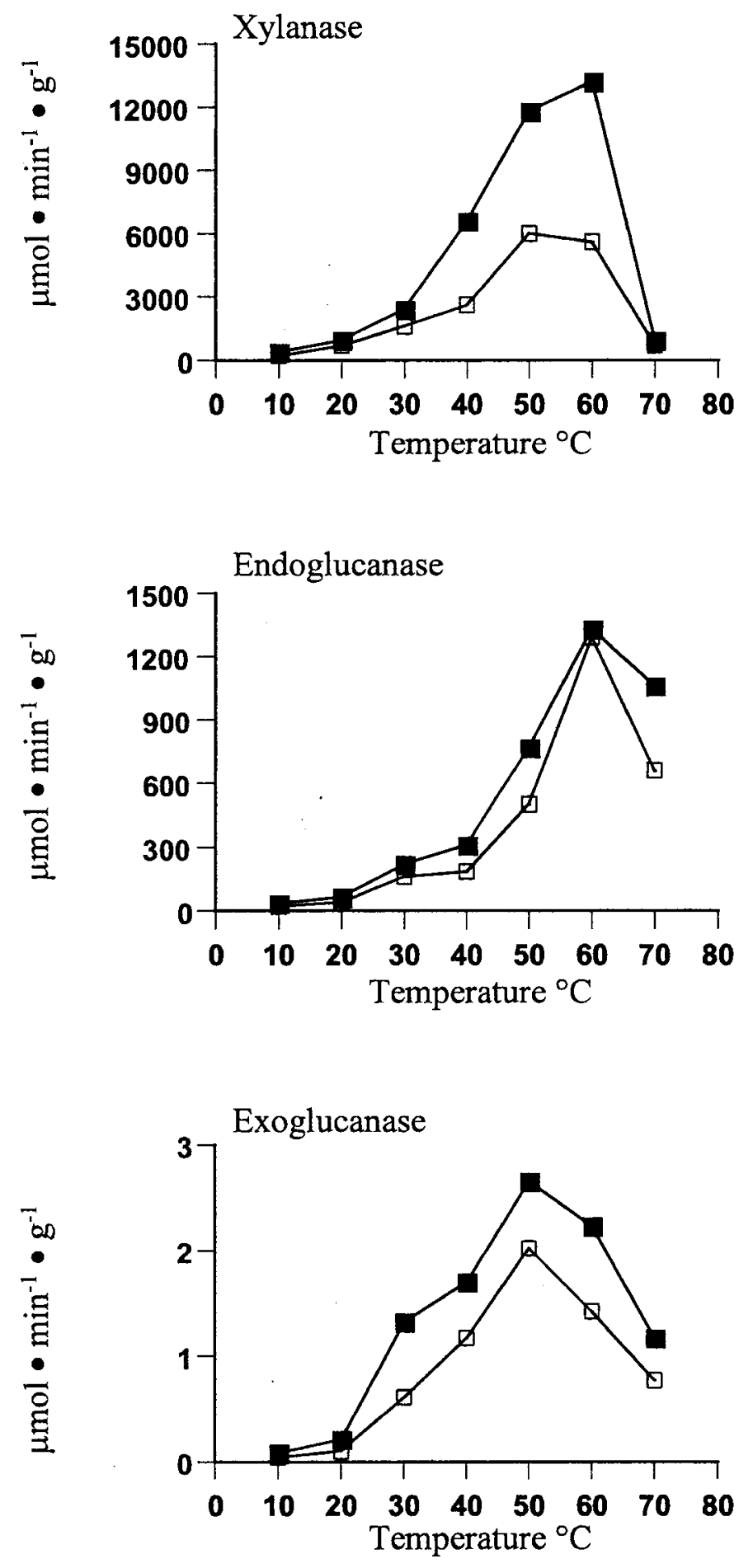

Figure 2. Effect of temperature on xylanase, endoglucanase, and exoglucanase activities of enzyme samples A (closed symbols) and B (open symbols). 
moderate fibrolytic activity, compared with the amount added, could occur within the rumen with these exogenous enzymes.

Wallace (1997) indicated that two roles supplemental enzymes could fill are either to amplify or complement ruminal activities. If their role was to amplify an existing activity, then the amount of activity added to the rumen would need to significantly add to that already present. Loss of activity at temperatures or $\mathrm{pH}$ values that significantly deviate from the optima would make this less likely. However, if complementing an existing activity, the combination of feeding high-energy diets and supplementing an enzyme with a $\mathrm{pH}$ optimum in the acidic range might be desirable (Wallace, 1994) and effective. Recent work by Morgavi et al. (2000) has shown the existence of a synergistic effect between ruminal and exogenous enzymes and that this can increase the hydrolytic potential within the rumen environment and could be an important mechanism by which enzyme additives improve fiber digestion. But with any diets and under any conditions, it would be necessary that the enzymes be effective near $39^{\circ} \mathrm{C}$ in order to have ruminal activity.

Although no effects of the direct-fed enzymes were recorded for milk production in the current study, reports using the same enzymes exist in the literature, which have shown significant milk yield responses (Zheng et al., 2000). Among a range of factors that could affect enzyme efficacy, diet composition may be extremely important as in studies with high concentrate-to-forage ratios rumen $\mathrm{pH}$ may be considerably closer to the optima for the enzymes, which could greatly improve fiber digestibility. In addition, a number of other factors such as method of application, specific enzyme complexes, time, and duration of enzyme application before feeding, dryness of the feed, dose rate, and stage of lactation in which the diet is fed can all influence milk production response noted with direct-fed enzyme additives. Wallace (2001) suggested that effects of fungal enzyme preparations are most likely at prefeeding. In the present study, enzymes were added each morning when mixing the TMR. Also, compounds that may or may not have fibrolytic activity in the enzyme mixtures may have acted as adjuvants that stimulated ruminal digestibility. If there were changes in the substrates that were used in producing the enzyme mixtures, these other compounds and/or activities may have changed as well.

Grant and Mertens (1992) have demonstrated that fiber digestion in the rumen is inhibited by low $\mathrm{pH}$, and a more favorable ruminal environment may stimulate growth rate of ruminal fiber-digesting bacteria; however, milk or other production variables were not improved by the addition of SSMA. Few published studies are available where SSMA or malic acid alone were fed to dairy cows (Kung et al., 1982). Most research with malic acid examined effects on ruminal organisms and are reviewed by Martin (1998). Results of previous studies indicate two potential mechanisms of production responses to supplemental SSMA. One potential mechanism is that malic acid may stimulate lactic acid uptake by Selenomonas ruminantium, resulting in a greater ruminal $\mathrm{pH}$. The lack of a production effect may indicate that ruminal acidosis was not a factor that affected milk production for the cows at these sites. Additionally, there was no indication of acidosis based on mean milk fat content (Table 4 and 5). Ruminal pH is affected by the fermentable carbohydrate in the diet. Nocek (1997) recommended that NSC in diets of dairy cows range from 30 to $40 \%$ to avoid acidosis. The average NFC at four sites was approximately $33 \%$ and at Cornell was $40 \%$. Fiber (ADF and NDF) percentages of the diets were well above the minimum amounts recommended by the current NRC (2001).

The second mechanism would be increased incorporation of ruminal ammonia by the addition of the soluble or nonstructural sugars. The diet may not have been limiting in soluble sugars because NSC was within the recommended range (Nocek, 1997), and diets were formulated at all sites using the CPM model with the restriction that MP allowable milk was $2 \mathrm{~kg} / \mathrm{d}$ greater than ME allowable milk.

\section{CONCLUSION}

Data from in vitro testing of the enzymes used in these studies indicate that most of the cellulase and hemicellulase activities are present; however, activity is lowered at $\mathrm{pH}$ and temperature conditions that exist in the rumen. No changes in milk production, milk composition, or BW gain were obtained in either trial in which supplemental enzymes or SSMA were added to the diet.

\section{ACKNOWLEDGMENTS}

The authors thank Dr. Jim Nocek, Mr. Doug Young, and the staff at the Spruce Haven Farm for their contributions to this study.

\section{REFERENCES}

Association of Official Analytical Chemists. 1990. Official Methods of Analysis. 15th ed. AOAC, Arlington, VA.

Bailey, M. J., P. Biely, and K. Poutanen. 1992. Interlaboratory testing of methods for assay of xylanase activity. J. Biotechnol. 23:257-270.

Barry, M. C., D. G. Fox, T. P. Tylutki, A. N. Pell, J. D. O'Connor, C. J. Sniffen, and W. Chalupa. 1994. A Manual for Using the Cornell Net Carbohydrate and Protein System for Evaluating Cattle Diets. Cornell Cooperative Extension. Ithaca, NY. 
Beauchemin, K. A., and L. M. Rode. 1996. Use of feed enzymes in ruminant nutrition. Pages 103-130 in Animal Science Research and Development-Meeting Future Challenges. L. M. Rode, ed. Minister of Supply and Services, Ottawa, Canada.

Beauchemin, K. A., L. M. Rode, M. Maekawa, D. P. Morgavi, and R. Kampen. 2000. Evaluation of a nonstarch polysaccharidase feed enzyme in dairy cow diets. J. Dairy Sci. 83:543-553.

Beauchemin, K. A., W. Z. Yang, and L. M. Rode. 1999. Effects of grain source and enzyme additive on site and extent of nutrient digestion in dairy cows. J. Dairy Sci. 82:378-390.

Chen, K. H., J. T. Huber, J. Simas, C. B. Theurer, P. Yu, S. C. Chan, F. Santos, Z. Wu, R. S. Swingle, and E. J. DePeters. 1995. Effect of enzyme treatment or steam-flaking of sorghum grain on lactation and digestion in dairy cows. J. Dairy Sci. 78:1721-1727.

Grant, R. J., and D. R. Mertens. 1992. Influence of buffer $\mathrm{pH}$ and raw corn starch addition on in vitro fiber digestion kinetics. J. Dairy Sci. 75:2762-2768.

Kung, L., Jr., J. T. Huber, J. D. Krummrey, L. Allison, and R. M. Cook. 1982. Influence of adding malic acid to dairy cattle rations on milk production, rumen volatile acids, digestibility, and nitrogen utilization. J. Dairy Sci. 65:1170-1174.

Kung, L., Jr., R. J. Treacher, G. A. Nauman, A. M. Smagala, K. M. Endres, and M. A. Cohen. 2000. The effect of treating forages with fibrolytic enzymes on its nutritive value and lactation performance of dairy cows. J. Dairy Sci. 83:115-122.

Lewis, G. E., W. K. Sanchez, C. W. Hunt, M. A. Guy, G. T. Pritchard, B. I. Swanson, and R. J. Treacher. 1999. Effect of direct-fed fibrolytic enzymes on the lactational performance of dairy cows. J. Dairy Sci. 82:611-617.

Martin, S. A. 1998. Manipulation of ruminal fermentation with organic acids: a review. J. Anim. Sci. 76:3123-3132.

Martin, S. A., H. M. Sullivan, and J. D. Evans. 2000. Effect of sugars and malate on ruminal microorganisms. J. Dairy Sci. 83:25742579.

Miller, G. L. 1959. Use of dinitrosalicylic acid reagent for determination of reducing sugars. Anal. Chem. 31:426-428.

Morgavi, D. P., K. A. Beauchemin, V. L. Nsereko, L. M. Rode, A. D. Iwaasa, W. Z. Yang, T. A. McAllister, and Y. Wang. 2000. Synergy between ruminal fibrolytic enzymes and enzymes from Trichoderma longibrachiatum. J. Dairy Sci. 83:1310-1321.
National Research Council. 1989. Nutrient Requirements of Dairy Cattle. 6th rev. ed. Natl. Acad. Sci., Washington, DC.

National Research Council. 2001. Nutrient Requirements of Dairy Cattle. 7th rev. ed. Natl. Acad. Sci., Washington, DC.

Nocek, J. E. 1997. Bovine acidosis: implications on lameness. J. Dairy Sci. 80:1005-1028.

Phipps, R. H., J. D. Sutton, and M. K. Bhat. 2002 Are enzymes usefu in ruminant diets? Proc. Brit. Soc. Anim. Sci. 247-248.

Rode, L. M., W. Z. Yang, and K. A. Beauchemin. 1999. Fibrolytic enzyme supplements for dairy cows in early lactation. J. Dairy Sci. 82:2121-2126.

SAS Institute Inc. 1997. SAS/STAT ${ }^{\circledR}$ Software: Changes and Enhancements Through Release 6.12, SAS Inst., Cary, NC.

Schingoethe, D. J., G. A. Stegeman, and R. J. Treacher. 1999. Response of lactating dairy cows to a cellulase and xylanase enzyme mixture applied to forages at the time of feeding. J. Dairy Sci. 82:996-1003.

Wallace, R. J. 1994. Ruminal microbiology, biotechnology, and ruminant nutrition: progress and problems. J. Anim. Sci. 72:29923003.

Wallace, R. J. 1997. Rumen microbiology and efficiency of digestion: Opportunities and impact of biotechnology. Pages 465-487 in Milk Composition, Production, and Biotechnology. R. A. S. Welch, D. J. W. Burns, S. R. Davis, A. I. Popay, and C. G. Prosser, ed. CAB International, New York, NY.

Wallace, R. J., S. J. A. Wallace, N. McKain, V. L. Nsereko, and G. F. Hartnell. 2001. Influence of supplementary fibrolytic enzymes on the fermentation of corn and grass silages by mixed ruminal microorganisms in vitro. J. Anim. Sci. 79:1905-1916.

Wood, T. M., and K. M. Bhat. 1988. Methods for measuring cellulase activities. Pages 87-112 in Methods in Enzymology. Vol. 160. W. A. Wood and S. T. Kellogg, ed. Academic Press, London.

Yang, W. Z., K. A. Beauchemin, and L. M. Rode. 1999. Effects of an enzyme feed additive on extent of digestion and milk production of lactating dairy cows. J. Dairy Sci. 82:391-403.

Yang, W. Z., K. A. Beauchemin, and L. M. Rode. 2000. A comparison of methods of adding fibrolytic enzymes to lactating cow diets. J. Dairy Sci. 83:2512-2520.

Zheng, W., D. J. Schingoethe, G. A. Stegeman, A. R. Hippen, and R. J. Treacher. 2000. Determination of when during the lactation cycle to start feeding a cellulase and xylanase enzyme mixture to dairy cows. J. Dairy Sci. 83:2319-2325. 